\title{
Halkla İlişkiler Mesleği Bağlamında Mobbing Olgusu
}

\author{
Esra Nur Akpunar ${ }^{\mathrm{a}}$ \\ aSosyal Bilimler Enstitüsü, Atatürk Üniversitesi, Erzurum, Türkiye
}

\begin{abstract}
ÖZET
Bu çalışmanın amacı, mobbing kavramının halkla ilişkiler için taşıdığı önemi tartışmaktır. Dokümanter analiz şeklinde yürütülen çalışmada veriler, ilgili literatürden derlenmiştir. Bu veriler, çeşitli başlıklar altında analiz edildikten sonra şu sonuçlara ulaşılmıştır: Mobbing, birçok nedene bağlansa da, esasta bir örgütsel iletişim sorunudur. $\mathrm{Bu}$ itibarla mobbing, işletmelerin iletişimden sorumlu birimi olan halkla ilişkilerle doğrudan alakalı bir sorundur. Sosyal psikoloji boyutu ağırlıklı bir olgu olmasına rağmen, literatürde mobbingin daha çok yönetim ve hukuksal boyutları ele alınmıştır. Bu durum, mobbing olgusunun bütün boyutlarıyla anlaşılması ve dolayısıyla da sorununun çözümünü geciktirmiştir. Sorunun çözümü noktasında, halkla ilişkilere önemli rol düşmektedir. Halkla ilişkiler mesleğinin saygınlığı ve etkililiği için, diğer boyutları yanında sorunun psikolojik boyutuna da odaklanmak önemlidir. Zira halkla ilişkilerin kurumdaki fonksiyonelliği, mobbingi tanıma ve elimine edebilme potansiyeli ile yakından ilişkilidir. Bu ilişki, mobbing gibi sorunların çözümünde halkla ilişkiler ile psikoloji disiplininin beraber çalışmasını gerekli kılmaktadır.
\end{abstract}

\section{MAKALE GEÇMIŞฺi}

Gönderim 12 Aralık 2016

Kabul 21 Aralık 2016

ANAHTAR KELIMMELER

Halkla ilişkiler; mobbing; çalışan psikolojisi

\section{Giriş}

Hangi sahada faaliyet gösterirse göstersin, günümüz işletmelerinde mobbing önemli bir sorundur. İşletmelerin, bu olguyu dikkate almama lüksü yok gibidir. Çünkü mobbing, çalışanın performansını düşürmekle kalmayıp, kurumun verimliliğini de sekteye uğratan kronik bir sorundur. Mobbing, birçok nedenle ilişkilendirilse de, temelde bir iletişim sorunudur. Bu durum mobbingi, işletmelerde bir iletişim mesleği olan halkla ilişkiler birimi ile doğrudan ilişkili bir soruna dönüştürür. Nitekim şimdilerde gölgede kalmış gibi görünse de, "halkla ilişkiler mesleğinin, psikoloji ve özellikle de sosyal psikoloji ile doğrudan ilişkili olduğu bilinmektedir” (Ustakara, 2011).

Literatürde "psikolojik şiddet" (Aydın, Şahin ve Uzun, 2007) olarak da adlandırılan mobbingi, halkla ilişkiler mesleği için önemli kılan öğe, bu olgunun işletmelerdeki halkla ilişkilerin fonksiyonlarını zedeleme riskidir. En küçük bir değişkenin bile önemli olduğu günümüzün rekabet dünyasında, hiçbir kurum veya kuruluş bu riski göz ardı edemez. Çünkü işletmeler için halkla ilişkiler birimi, yönetimin başarısında ve işletmenin hedeflerine ulaşmasında önemli rol oynamaktadır (Ciğerdelen, 2006). Halkla ilişkiler, bir işletmenin amaçlarına ulaşabilmesi için iletişimden sorumlu özgün bir yönetim fonksiyonudur (Dinçer, 2009). Halkla ilişkiler; örgüt ve onun hedef kitlesi arasında karşılıklı anlayış, işbirliği ve güvenin sağlanması için örgüt içindeki ve dı- 
şındaki tümplanlı iletişim çabalarını içermektedir. (Çakmak ve Kilci, 2011, s. 221). Halkla ilişkiler çalışmaları, kurum içi ve kurum dışı olmak üzere ikiye ayrılmaktadır. Çalışanlara yönelik halkla ilişkiler, şirket içi iletişimi hedefler (MEGEP, 2007). Halkla ilişkiler, iç ve diş hedef kitle ile etkileşimde bulunarak kurumun imajının oluşumuna çok büyük katkılarda bulunmaktadır (Özkan, 2009).

Sayısı arttırılabilecek olan bu tanımlardaki değişmeyen ortak payda, iletişimdir. Bu itibarla mobbing, "etik dişı bir iletişim biçimi” (Geçikli ve Geçikli, 2012, s. 54) veya "bir iletişim çatlağı” (Köse, 2006) olarak, halkla ilişkiler birimi ile doğrudan ilişkili bir tehdittir. Dolayısıyla işletmelerin hedeflerine ulaşabilmesi için kritik role sahip hakla ilişkiler biriminin, bu fonksiyonunu icra edebilmesinde mobbing kritik öneme sahip bir olgudur. Mobbing, küresel çağın enformasyon toplumu işletmelerinin karşılaştıkları ciddi iletişim sorunlarından biridir (Köse, 2006). Bundan dolayı, daha çok yönetimsel ve hukuksal boyutları öne çıkarılmış olan mobbing kavramının, halkla ilişkiler mesleği bağlamında irdelenmesi önemlidir.

\section{Yöntem}

Araştırmalar veri toplama tekniklerine göre görgül (ampirik, gözleme dayalı) ve belgesel (doküman) araştırmaları olmak üzere ikiye ayrılır. Araştırmacı tarafından ihtiyaç duyulan verilerin alan yazın taraması ile elde edildiği araştırmalar, belgesel araştırmalardır (Büyüköztürk, 2004). Amacı, mobbing kavramını halkla ilişkiler mesleği bağlamında irdelemek olan bu çalışmanın yöntemi, belgesel araştırmalar grubunda yer alan literatür taramasıdır. Tarama modeli, bir nesne veya birey hakkında tutulmuş çeşitli kaynaklara başvurarak, elde edilen verileri bir sistem içinde bütünleştirerek yorumlamaktır (Karasar, 2000). Dokümanter analiz şeklinde yürütülen bu teorik çalışmada, halkla ilişkiler ve mobbing kavramı arasındaki ilişkiyi saptamak amacıyla yazılı ve elektronik literatürde yer alan bilimsel niteliklere haiz kitap, makale, bildiri, raporlar taranmıştır. Belgesel kaynak derlemesi (Dokümanter analizi), bir konu hakkındaki yazı ve belgelerin analizi ve incelenmesidir (Yıldırım ve Şimşek, 2006, s. 187; Seyidoğlu, 1997, s. 43). Çalışmada taranan dokümanlar, çalışmanın amacı doğrultusunda üç başlık altında toplanarak irdelenmiştir. Bu irdeleme akabinde çeşitli değerlendirmeler yapılarak birtakım sonuçlara ulaşılmıştır.

\section{Halkla İlişkilerin Tanımı ve Önemi}

Sosyal ve beşeri bilimlerdeki birçok kavram gibi halkla ilişkilerin de birçok tanımı bulunmaktadır. Bunun önemli bir nedeni, halkla ilişkilerin disiplinler arası yapıda olmasıdır (Ustakara, 2011). Halkla ilişkiler konusundaki tanım fazlalığını "sorun” olarak gören Aktaş ve Özdemir (2006, s. 36), bunun nedeni olarak," ya alanın çok genç ya da köklü olmasına” gönderme yapmaktadırlar. 1970'lere kadar 470 civarında halkla ilişkiler tanımı derleyen Rex Harlov; bu kavramı, "kuruluş ve hedef kitlesi arasında karşılıklı iletişimi, anlayışı, kabulü ve işbirliğini kurma ve sürdürmeye yardım eden bir yönetim işlevidir" biçiminde tanımlamaktadır (Ayhan, 2006).

Halkla ilişkilerin, "yönetenlerin yönetilenlere bilgi vermesi ve onlardan geri besleme alması" anlamında tarihsel arka planının Antik Yunan'a kadar götürülebileceği belirtilmektedir (Yıldız, 2006, s. 126). Gelişmiş ülkelerde 1950'lerde kullanılmaya başlanan 
hakla ilişkiler kavramı, Türkiye'de ise esas olarak 1980'li yıllardan sonra telaffuz edilmeye başlanmıştır. İngilizce’de "public relations" kavramının karşılığı olarak dilimize çevrilen halkla ilişkiler (Aktaş ve Özdemir, 2006, s. 36), ele alınış bağlamına göre çeşitli şekilde tanımlanabilmektedir. Ciğgerdelen (2006), halkla ilişkileri en kısa tanımıyla "tanıtma ve tanınma çabaları" şeklinde ifade etmektedir. "Tanıtma ve Tanınma" tanımı kısa olmakla birlikte işletme yönetimini, işletmenin misyon ve vizyonunu, kurum içi ve dişı hedef kitleyi, iletişim stratejisini, iletişim araç ve yöntemlerini vs. gibi pek çok kavramı da içermektedir. Bernays’a göre halkla ilişkiler, "halk desteğini, bilgi, ikna ve düzenleme yoluyla, bir eylem, amaç, hareket ya da kurum için harekete geçirme girişimidir" (Akt: Ustakara, 2011, s. 174). Bu anlamda halkla ilişkiler "kamuoyu oluşturma" olarak özetlenebilir (Yıldız, 2006, s. 127). Diğer bir tanımla halkla ilişkiler, özel ya da kamu kurum/kuruluşlarının belirlenmiş hedef kitlelerini etkilemek için hazırlanmış planlı, inandırıcı bir iletişim çabası ve yönetim fonksiyonudur (Vural ve Coşkun, 2006). Halkla ilişkilerin birçok başka faaliyetle karıştırıldığını ifade eden Kazancı'ya (1980) göre, hakla ilişkiler uygulamalarının temelinde iletişim yatar. Halkla ilişkiler; yönetim tarafından belirlenen politika ve faaliyetlerin çeşitli kanallar aracılığı ile halka iletilmesi, iletilen mesajın halkta bıraktığı etkinin ölçülmesi ve değerlendirilmesi, varsa aksaklıkların düzeltilerek yeniden halka sunulması ve halkın gözünde olumlu imaj sağlanması yönünde yürütülen çalışmalardır (Çakmak ve Kilci, 2011). Halkla ilişkiler, hedef kitleleri arasında karşılıklı iletişimi, anlamayı, kabulü ve işbirliğini sağlayıp sürdürülmesine yardım eden yönetim fonksiyonudur (Dinçer, 2009).

Halkla ilişkileri çalışma alanı ve bir meslek bağlamında ele alan Ustakara (2001), halkla ilişkiler mesleğinin, disiplinler arası bilgi birikimini gerekli kılan bir yapıda olduğuna dikkat çekmektedir. Bir halkla ilişkiler uzmanı, sosyal bilimlerin her alanında genel bir bilgi havzasına sahip olmak durumundadır. Bunlar arasında ekonomi, sosyoloji, psikoloji ve siyaset bilimi en önde gelenleri olarak göze çarpmaktadır. Halkla ilişkileri, stratejik yönetimde yer alan önemli bir disiplin olarak kabul eden Demir'e (2012) göre, bu disiplin, kamuoyunu etkileme ve yönetme rolü üzerinde odaklanmıştır. Günümüzde ise halkla ilişkiler, işletmelerde iç ve dış çevreler arasında karşılıklı iletişimi sağlayan bir yönetim fonksiyonu olarak kabul görmektedir (Eskiyörük, 2010). Değişik bakış açısıyla Sümer (2013), hakla ilişkilerin faklı ülkelerdeki bağlamlarına ve örgütü meşru kılmadaki rolüne dikkat çekmektedir. Burada kısaca temas edilen halkla ilişkiler tanımlarından çıkan ortak sonuçlar şöyle özetlenebilir (Çakmak ve Kilci, 2011, s. 223):

- Halkla ilişkiler, yönetimin bir işlevidir.

- Halkla ilişkilerde amaç karşı kitleyi etkilemek, inandırmak ve bir eyleme yönlendirmektir.

- Halkla ilişkiler karşılıklı iletişim yani etkileşime dayanan bir iletişim sürecini içerir.

- Halkla ilişkiler birimi kuran kuruluş için ümit edilen fayda, karşı kitlenin güven ve ilgisini kazanmaktır.

- Halkla ilişkiler, örgütün kâr amacı yanında sosyal sorumluluğunun da olduğunu kanıtlayacak biçimde davranmasına yardımcı olur. 
- Halkla ilişkiler faaliyetleri hem özel sektör hem de kamu alanında uygulama bulmaktadir.

- Halkla ilişkiler faaliyetleri bir kereye mahsus düzenlenen faaliyetlerden ziyade, sürekli olarak ve bir plan çerçevesinde gerçekleştirilen eylemlerdir.

- Halkla ilişkilerin hedef kitlesi hem kurum dişı çevre hem de kurum içi çevrenin unsurlaridir.

Halkla ilişkilerin tanımından sonra, konunun kamu ve özel sektör için önemine değinmekte yarar vardır. Halkla ilişkiler, günümüzde organizasyonların göz ardı edemeyecekleri ölçüde öneme sahip bir durum arz etmektedir (Taş ve Kestellioğlu, 2011). Yıldırım’a (2008) göre, ekonomik rekabetin artması, uluslararası ilişkilerin önceki yıllara göre kıyaslanamayacak ölçüde gelişmiş olması, kitle iletişimindeki gelişmelerle dünyamızın küçük bir köye dönüşme yolunda hızla ilerlemesi halkla ilişkilerin önem kazanmasında etkili olmuştur. Öner (2001, s. 101), kamu kurumları bağlamında halkla ilişkileri aşağıdaki şekilde tanımlamaktadır:

Halkla ilişkiler, bir kamu kuruluşunun ilişkide bulunduğu toplum kesiminin güven ve desteğini sağlamak için giriştiği, iki yönlü iletişime dayalı, sonuçta kamuoyunda kuruluşun, kuruluşta da toplumun istediği yönde değişikliklerin gerçekleşmesine, böylece kuruluş ile çevresi arasında olabilecek en uygun ölçekte uyum ve denge sağlanmasına yönelik sistemli ve sürekli çabalardır.

Benzer şekilde halkla ilişkileri, kamu bağlamında ele alan Akçakaya (1999), bu birimin toplum kesiminin güven ve desteğini sağlamadaki işlevine dikkat çekmektedir. Halkla ilişkileri, bir kuruluşun hem sigortası, hem vitrini olarak ifade eden Taştekin'e (2007) göre, özellikle kamu sektörü için bu birimin sağlayacağı toplumsal destek ve güven vazgeçilmezdir. Konuya eleştirel yaklaşan Ayhan (2006), halkla ilişkileri "kamuda zaten uygulama alanı pek bulamayan ya da kupür kesmekle özdeşleşen bir uğraş olarak” algılandığını ifade etmektedir. Bunun halkla ilişkileri, zamanla sıradanlaştırdığını belirten yazara göre, gelişmiş ülkelerde halkla ilişkilere ciddi önem verilmektedir. Aynı paralelde Ciğerdelen (2006), halkla ilişkiler biriminin, işletmenin hedeflerine ulaşmasındaki önemli payına dikkati çekmektedir. Halkla ilişkileri bir "algı yönetimi” olarak ifade eden Ustakara (2011), buna, "işletmenin itibarını” da eklemektedir. Aktaş ve Özdemir (2006) ise, halkla ilişkilerin yirminci yüzyılda giderek artan önemine ve uygulama alanındaki gelişmesine paralel olarak, konu hakkındaki akademik literatürdeki gelişmelere dikkat çekmişlerdir. Küresel bazda halkla ilişkilere verilen önemi göstermesi bakımından, ABD'de 100 bini aşkın halkla ilişkiler görevlisi ve 6000'in üzerinde halkla ilişkiler ajansı bulunurken; Türkiye'de bu rakam 75 civarındadır. Çin'de ise, halkla ilişkiler öğrenimi gören öğrenci sayısı 250 bin dolayındadır (Ayhan, 2006).Türkiye'de ise, son yıllarda ekonomideki önemli gelişmelere rağmen, bir türlü istenilen sıçramayı yapamayan birçok işletme varken, binlerce halkla ilişkiler mezununun iş araması, mesleğin ülkemizdeki durumunu özetler niteliktedir.

\section{Mobbing Kavramı}

Mobbing, birçok bağlamda ele alınabilen bir kavramdır. Bu çalışmada mobbing kavramı 
daha çok işyerinde kişilerarası iletişim ve etkileşim sorunu bağlamında ele alınmıştır. İşyerinde karşılaşılan iletişimle ilgili tüm olumsuz davranışları mobbing ile karıştırmamak için, bu kavrama yakından bakmakta yarar vardır. Etimolojik olarak mobbing, Latince "kararsız kalabalık" olan "mobile vulgus” dan türemiştir. "Mobbing” sözcügü ise, çevresini kuşatma, topluca saldırma ya da sıkıntı verme anlamındadır (Koç ve Bulut, 2009). İngilizce "mob" kökünden türetilmiş olan mobbing, birini istila etmek üzere zulüm ve saldırı anlamındadır (Divincova ve Sivakova, 2014). Bir iletişim çatlağı olan ve çalışana sıkıntı veren mobbing, literatürde, psikolojik şiddet, psikolojik-duygusal taciz, psikolojik terör, zorbalık (Çiftçi, vd., 2013), yıldırma, bezdirme vb. isimlerle de anılmaktadır.

Kavram karmaşasını önlemek için Türk Dil Kurumu (TDK), mobbing kavramının karşılığını "bezdiri" olarak ifade etmiştir (Keskin ve Canbaz, 2014, s. 165). Buradaki "bezdiri" kavramını ifade etmek için de, "psikolojik şiddet, ofis içi psikolojik şiddet, örgütsel baskı, duygusal baskı, duygusal taciz, duygusal zorbalık, psikolojik terör, duygusal saldırı, iş yerinde zorbalık" gibi terimler kullanılmaktadır (Demir, 2009). Mobbingle Mücadele Derneği (2011), mobbing için "manevi şiddet” teriminin kullanılmasını önerirken; Crawshaw (2009), "başat engel" (major barrier) ve Sloan ile arkadaşları da (2010), "grup zorbalığı” terimlerini öne çıkarmaktadır. Mobbing kavramını literatüre kazandıran Leymann ise, "bullying” kavramını okul örgütleri için; "mobbing” kavramını da işyerleri için kullanılmasını önermektedir (Turan, 2006). Konuyu yönetim ve liderlik bağlamında ele alan Dabu ve Draghic'e (2013) göre, hoşgörüsüz yönetim mobbingi doğururken; otoriter yönetim ise bullyinge yol açmaktadır.

İşyerinde yaşanan her olumsuz davranış mobbing sayılamaz. Leymann’a (1990) göre, çalışanların maruz kaldığı istenmeyen davranışların mobbing olarak tanımlanabilmesi için, bu davranışların en az altı ay boyunca ve haftada en az bir kez tekrarlanması gerekmektedir. Bu yüzden birçok mobbing tanımında "sistematik" terimi bulunmaktadır. En genel anlamda mobbing, çalışanın maruz kaldığı istenmeyen davranışlardır. Bu istenmeyen davranışlar, işyerinde belirli kişileri hedef alan sistematik duygusal saldırı ve yıpratma hareketleridir. Çalışanda profesyonel itibar kaybına yol açan bu düşmanca eylemler ve saldırganlıklar (sözel, fiziksel, cinsel) mobbing olarak tanımlanabilir (Cornoiu ve Gyorgy, 2013). Mobbing, işyerindeki psikolojik taciz olup; çalışanı dedikodu, yıldırma, izolasyon ile onu aşağılayarak mesleki yetkinliğini tehdit eden bir olgudur. Mobbing, haksız yere suçlama, ima, kinaye, dedikodu yoluyla itibarı sarsma, küçük düşürme, taciz, duygusal istismar ve şiddet uygulayarak, bir kişiyi, işyerinin dışına çıkmaya zorlayan kötü niyetli davranışları kapsar (Tetik, 2010, s. 81). Bir anlamda kronik bir çatışma olan mobbing, çalışana yönelik her türlü incitici, küçük düşürücü, yok sayan durumlar (Çomak ve Tunç, 2012, s. 198) ile her türlü rahatsız edici sataşma, imalarda bulunma, vücut diliyle hakaret ve aşağılama ile fiziki şiddeti içeren saldırıları kapsar. Shallcross, Sheehan ve Ramsay (2008), bunlara, gizli söylenti, dedikodu ve imaları da eklemektedir. Ancak mobbing, iş yeri şakası, etik olmayan davranış örnekleri ve iş yerinde izole çatışmaları kapsamaz.

Literatürde mobbinge ilişkin birçok farklı tanım mevcuttur. Bunun önemli bir nedeni, mobbingin oldukça karmaşık bir olgu olmasıdır. Mobbing, işyerinde gizli, hedefli ve yaygın biçimde kullanılan kötüye kullanım biçimidir (Sloan vd., 2010). Bu kavramı "saldırganlık sendromu" olarak ifade eden Shallcross'a (2008) göre, mobbing, bir kişiyi işyeri dışına zorlamak için yapılan kötü niyetli bir girişimdir. Köse (2006), 
mobbingi, "kurbanın kendisini ifade etme olanağının sınırlandırıldığı, sürekli olarak sözünün kesildiği, kişiliğinin aşağılanarak ve bu şekilde damgalanarak yeniden tanımlandığı, kimliğinin buna göre kurulduğu bir dışlama ve kara propaganda yürütme süreci" olarak tanımlamaktadır. Mikkelsen (2004) ise, mobbingi, "kişilerarası iletişim süreci içerisinde göndericinin (saldırgan) alıcının (kurbanın) kişiliğine veya yaptığı işe yönelik olumsuz ve saldırganlık öğeleri içeren, sözlü veya sözlü olmayan iletişim biçimlerini kısıtladığı bir sosyal etkileşim” olarak tanımlamıştır (Akt: Avcı ve Kaya, 2010, s. 55). Farklı bir bakış açısıyla, Cemaloğlu (2007), mobbingi, "örgütlerdeki sosyal stres kaynaklarının en uç noktası” olarak nitelendirmektedir. Browne ve Smith'e (2008) göre, mobbing, doğrudan bir çalışana (kurbana) yönelik, sistemli ve uzun süreli ciddi psikolojik ve fizyolojik hasarlara sebep olabilecek davranışlardır (Akt. Tetik, 2010). Meslek hastalığı olarak da nitelendirilen mobbing, işyerinde hedef seçilmiş bir çalışanın, bir ya da birden fazla kişi tarafından sürekli olarak kötü niyetli ve sağlığını tehlikeye sokacak tarzda olumsuz davranışlara maruz bırakılmasıdır (Namie ve Namie, 2000 Akt: Tınaz, 2013, s. 25). Mobbing, doğrudan veya dolaylı bir şekilde, planlı, sistematik ve bilinçli bir baskı yapmak anlamına gelmekte ve karşı tarafı pasifize etmek amacı taşımaktadır (Palaz vd., 2008).

Mobbingi doğuran sebepler konusunda da literatürde çok farklı nedenlere gönderme yapılmaktadır. İşletmelerin yönetim sorunu bunların başında gelmektedir. Nitekim Dabu ve Draghic'e (2013) göre, mobbingin nedeni hoşgörüsüz yönetimdir. Bunu, örgütlerdeki iletişim kanallarının açık olmaması, aynı pozisyona birden çok çalışanın talip olması, zor çalışma koşulları, kişisel özellikler ve kültürel etmenler izlemektedir. Demir'e (2009, s. 102) göre, işletmelerde mobbingin belirli nedenleri olmamakla birlikte, pek çok mobbing olayını kişisel kıskançlıklar tetiklemektedir. Mobbingin potansiyel sebepleri olarak; "örgütsel iklim, yüksek stres ve örgütsel sorunlar; mağdurun kendisi ve sosyal sistem"; "kurbanın çalışkan ve geleceğinin parlak olması, işini çok iyi yapması gibi kişisel özellikler" (Zapf, 1999) öne çıkmaktadır. Bunlardan başka mobbingin nedenleri olarak, "psikolojik şiddet uygulayıcısının duygusal rahatsızlıkları, insani ve etik değerlerden uzak kişisel özellikleri ve mevkiini kaybetme korkusu" gibi sebepleri sıralamak da mümkündür (Akt. Karcıoğlu ve Akbaş, 2010, s. 142). Arpacioğlu'na (2003) göre, örgütsel yapının katı, hiyerarşi basamaklarının fazla olması, iletişim kanallarının kapalı olması, stresli iş ortamı, mobbingin örgütsel nedenleri arasında yer almaktadır. Demirci ve Büyük (2010), mobbingi doğuran kişilik özelliklerini şu şekilde sıralamaktadır: yeni fikirler üretebilen, farklı bakış açılarıyla dünyayı yorumlayabilen, eğitim, dış görünüş, entelektüel birikim açısından parlak eleman veya işe yeni başlamış deneyimsizlik, rekabetçi ve bencil kişiliğe sahip olmak (Akt: Özgan, Kara ve Arslan, 2013). Palaz vd. (2008) bu konuda yaşanan teknolojik değişimlerle birlikte görülen yapısal dönüşümlere dikkat çekmektedir.

Genel olarak en az iki tip mobbingden söz edilmektedir. Biri hassas mobbing, diğeri ise stratejik mobbingdir. İlkinde, olaylar iki kişi arasında gerçekleşmektedir. Stratejik mobbingde ise örgüt, kasıtlı olarak çalışanlarına mobbing uygulamaktadır. Örgütlerde en sık görülen mobbing türünün güç eşitsizliğine dayanan yukarıdan aşağıya doğru uygulanan mobbing olduğu araştırmalardan anlaşılmaktadır (Çelen ve Uluğ, 2014, s. 196). Keashly ve Neuman (2008 Akt: Karatuna, 2013) işyerinde mobbingi dört boyut altında değerlendirmiştir: Bunlar, Kişiyi engelleyen, hiçe sayan davranışlar. Kaba, saygısız, düşmanca ve küçük düşürücü davranışlar. İşle ilgili davranışlar ve hakaretler, kişisel saldirilardır. 
Son çalışmalar, mobbingin dünya ölçeğinde oldukça yaygın olduğunu göstermiştir. Örneğin ABD’de 127 milyonluk işgücünün dört milyonu, mobbing kurbanıdır. Bazı yayınlarda bu rakam 20 milyona kadar çıkartılmaktadır (Shelton, 2011). Araştırmalar, ABD'de çalışanların \%13'ünün (yaklaşık 15 milyon) mobbinge maruz kaldığını göstermektedir (SHARP, 2011). Avrupa'da ise, ortalama olarak çalışanların \% 5-10'unun, herhangi bir zamanda mobbinge maruz kalmakta olduğu belirtilmektedir (Einarsen, 2005). Türkiye'de, konuyla ilgili Başbakanlık Genelgesinin 2011 tarihinde yürürlüğe girmesiyle ALO 170'e çok sayıda şikâyette bulunulmuş olması, mobbingin ülkemizde de yaygın bir sorun olduğunu göstermektedir (Etyemez, 2013). Burada kısaca temas edilen ve her iş yerinde görülebilecek olan mobbingin, gerek çalışan ve gerekse örgüt üzerinde tahrip edici sonuçları vardır. Dolayısıyla ağırlıklı olarak bir iletişim sorunu olan mobbing, diğer birimlerden çok, öncelikle işletmelerin iletişimden sorumlu birimi olan halkla ilişkilerin fonksiyonlarını olumsuz etkilemektedir. Bu itibarla mobbing kavramı bir halkla ilişkiler sorunu olarak ele alınmalı ve kavramın yönetimsel, hukuksal ve sosyolojik yönleri kadar, psikolojik boyutunun da dikkate alınması önemlidir.

\section{Sonuç}

Son yıllarda her sahada olduğu gibi iş yaşamında da, insan unsuru ön plana çıkmaktadır. Buna paralel olarak, gerek kamu ve gerekse özel sektöre ait kurum ve kuruluşlarındaki halkla ilişkiler birimi, daha önce olmadığı kadar dikkat çekmektedir. Çünkü halkla ilişkiler birimi, örgütün insanlarla doğrudan ilişkili yüzünü temsil etmektedir. Burada ön plana çıkarılan insan, bir işyerinde çalışan "bütün insandır". Beden, zihin, kalp ve ruhtan müteşekkil bütün insan (Covey, 2005), ancak bu bütünlüğü koruyabildiği zaman potansiyelini tam olarak açığa çıkarabilir. Zaten tüm kurum ve kuruluşlarının da peşinde olduğu bu değil midir? Yine Covey'in tabiriyle ve çoğunlukla olan biçimiyle, bir kurum ve kuruluşta çalışanın sadece zihin ve bedenine odaklanıp; kalbi (duyguları) ve ruhu görmezden gelindiğinde ne olur? Çalışma yaşamındaki birçok sorunun temelini teşkil eden "düşük güven" vukua gelir. Bir işletmede düşük güven veya güven kaybının kişisel ve kurumsal maliyeti çok ağır olabilir. Bu maliyet, huzursuz çalışanlar ve dolayısıyla da bu çalışanlarının potansiyelinden tam olarak yararlanamayan düşük verimli işletmeler şeklinde özetlenebilir. Ne büyük kayıp ve israf! Hele de, dürüstlük, inandırıcılık ve güvenirlilik ilkelerine dayalı faaliyet gösteren halkla ilişkiler (Güllüoğlu, 2006) birimi için. Bu konuda, Ustakara (2011), halkla ilişkilerin paydaşlarla iletişiminde onları ikna edebilmek için önce kurumsal güven inşasının gerekliliğine vurgu yapmaktadır. Kurumsal güven inşası ise, her şeyden önce anti-mobbing bir örgütsel çalışma iklimine bağlıdır. İşte halkla ilişkilerin, bu iklimi inşa etme ve çalışanla yöneticiler veya çalışanlar arasındaki güven kaybını önlemede önemli rolü vardır. Halkla ilişkiler biriminin bu rolünü yerine getirmesi büyük oranda, birer insan olan çalışanların insani özelliklerini daha iyi tanımaktan geçer. Bu noktada, insanın duygusal ve ruhsal sağlığı ile yakından ilişkili olan mobbing kavramı, halkla ilişkilerin öncelikli konusu ve sorunu olarak öne çıkar. Halkla ilişkiler birimi için mobbing, artık sadece hukuksal ve yönetsel değil; çalışanın total performansı üzerinde son derece etkili olan psikolojik bir olgudur. Bu durum, Halkla ilişkiler biriminin, kendisinden beklenen fonksiyonları icra edebilmek için mobbing sorununu daha derinlikli olarak ele almasını gerektirir. Ustakara'nın (2011) tabiriyle, "halk- 
la ilişkiler, psikolojik tasarım boyutuna odaklanarak kurumdaki fonksiyonunu daha etkili yerine getirebilir". Zira halkla ilişkiler biriminin başarısı, bir taraftan, bu birim çalışanlarının yetkinlik, bilgi, beceri ve yaratıcılıkları kadar (Ciğerdelen, 2006), ruh durumlarıyla da yakından ilişkilidir. Örgütün moral, motivasyon, iş tatmini, performans, örgütsel bağlılık ve dolayısıyla da verimliliği (Yılmaz, Özler ve Mercan, 2008) için bu son derece önemlidir. Zaten örgütün halkla ilişkiler biriminin görevi de bu değil midir? Halkla ilişkiler disiplini ile psikoloji disiplinini birlikte ele alan disiplinler arası çalışmalar, bu konuda ciddi katkı sağlayabilir. Kaldı ki işyerinde birey, grup ve işletmeler için olumsuz sonuçlara yol açan mobbing, tek başına bir bilim veya disiplinin başa çıkamayacağı kadar kompleks bir olgudur (Shallcross, Sheehan ve Ramsay, 2008). Bu itibarla, işletmelerin hedeflerine ulaşması için halkla ilişkiler birimi ne kadar önemli ise; halkla ilişkilerin fonksiyonelliği de mobbing ile mücadele kapasitesine bağlıdır denilebilir. Zira halkla ilişkiler biriminin başarısı, bir taraftan, bu birim çalışanlarının yetkinlik, bilgi, beceri ve yaratıcılıkları kadar (Ciğerdelen, 2006); bütün bunları bozguna uğratma riski taşıyan mobbingi tanıma ve elimine edebilme potansiyeliyle de yakından ilişkilidir. Bu ilişki, halkla ilişkiler biriminin, "başkalarının bakış açısına göre takdim etme kapasitesini artırmak için, önce kendi imgesini kurmasını” (Köse, 2006) gerektirir. Bunun için ise, halkla ilişkiler mesleği, iletişim, hukuk, yönetim, politika, sosyoloji, ergonomi ve etik ile ilişkilendirildiği kadar, psikoloji ve sosyal psikoloji disiplini ile ilişkilendirilmelidir.

\section{Kaynakça}

Akçakaya, M. (1999). Belediyelerde Halka İlişkiler. Sayıştay Dergisi, 34,77-91.

Aktaş ve Özdemir, (2006). Disiplinler arası Bir Alan Olarak Halkla İlişkiler: Türkiye'deki Akademik Çalışmalar Üzerine Niteliksel Bir İnceleme. II. Ulusal Hakla İlişkiler Sempozyumu, 27-28 Nisan 2006, Kocaeli Üniversitesi.

Arpacıoğlu, G. (2005). Türkiye’de Zorbalık Bir Çalışma Biçimi İçinde İnsan Kaynaklarında Yeni Eğilimler (Ed. D. Yalım). İstanbul: Hayat Yayıncılık.

Avcı, U. ve Kaya, U. (2010). Yıldırma (Mobbing) ve Kişilik İlişkisi: Hizmet Sektörü Çalışanları Üzerinde Bir Araştırma. Afyon Kocatepe Üniversitesi, İ.İ.B.F. Dergisi, XII (II).

Aydın, Ş., Şahin, N. ve Uzun, D. (2007). Örgütlerde Yaşanan Psikolojik Şiddet Sorunlarının Konaklama İşletmeleri Açısından Değerlendirilmesi. Ç.Ü. Sosyal Bilimler Enstitüsü Dergisi, 16 (2), 61-74.

Ayhan, A. (2006). Halkla İlişkiler Önlisans Öğrencilerinin Halkla İlişkilere Bakış Açısı, Okul Sonrası Beklenti ve Kaygıları. II. Ulusal Hakla İlişkiler Sempozyumu, 27-28 Nisan 2006, Kocaeli Üniversitesi.

Büyüköztürk Ş. (2004). Veri Analizi El Kitabı. Ankara: Pegem A Yayıncılık.

Cemaloğlu, N. (2007). Okul Yöneticilerinin Liderlik Stilleri İle Yıldırma Arasındaki İlişki. Hacettepe Üniversitesi Eğitim Fakültesi Dergisi, 33, 77-87.

Ciğerdelen, T. (2006). Kocaeli Bölgesindeki Halkla İlişkiler Uzmanlarının Profiline Yönelik Bir Araştırma. II. Ulusal Hakla İlişkiler Sempozyumu, 27-28 Nisan 2006, Kocaeli Üniversitesi.

Cornoiu, T.S. ve Gyorgy, M. (2013). Mobbing in Organizations. Benefits of Identifying the Phenomenon. Procedia - Social and Behavioral Sciences, 78, 708 - 712.

Covey, S. R. (2005). 8’inci Alışkanlık- Bütünlüğe Doğru (Çev: Sezer Soner ve Çağlayan Erendağ). İstanbul: Sistem Yayıncilık. 
Crawshaw, L. (2009). Workplace bullying? Mobbing? Harassment? Distraction by a Thousand Definitions. Practice and Research, 61(3), 263-267.

Çakmak, A. F. ve Kilci, S. (2011). Kamu Yönetiminde Halkla İlişkilerin Yeri ve Önemi. Kamu-İşs, 11 (4), 219-270.

Çelen, C. B. ve Uluğ, F. (2014). Türkiye’de Yapılan Mobbing Araştırmaları Üzerine Bir Analiz. II. Örgütsel Davranış Kongresi, 7-8 Kasım Kayseri, Bildirileri, (Editörler: M. Özdevecioğlu, T. Dedeoğlu ve N. Çapar) Kayseri: Doğuş Ofset.

Çiftçi, G.E., Öneren, M. ve Önem, A. (2013). Çalışanlarda Psikolojik Yıldırma ve Endişe Düzeyi. "İş, GÜÇ" Endüstri İlişkileri ve İnsan Kaynakları Dergisi, 15 (2), 63-81.

Çomak, E. ve Tunç, B (2012). İlköğretim Öğretmenlerinin İlköğretim Okullarında Yaşadıkları Yıldırma Durumları. Mersin Üniversitesi Eğitim Fakültesi Dergisi, 8(3), 197-208.

Dabu, B. ve Draghic, A. (2013). Mobbing and Bullying in Business Organizations and Consequences on Human Health. Economic Sciences, 12(1), 63-71.

Demir, F. (2012). Halkla İlişkiler Yönetimi. Eskişehir: Anadolu Üniversitesi Yayını No: 2603.

Demir, Y. (2009). Mobbing’in Kişisel ve Örgütsel Etkileri Üzerine Bir Araştırma. Sosyal Bilimler Enstitüsü Dergisi, 3, 99-111.

Dinçer, C. (2009). Pazarlamada Halkla İlişkilerinin Önemi ve Rolü: Kobiler Üzerine Bir Araştırma. Akademik Araştırmalar ve Çalı̧̧malar Dergisi, 1(1), 38-46.

Divincova, A. ve Sivakova, B. (2014). Mobbing at Workplace and its Impact on Employee Performance.

Human Resources Management \& Ergonomics, VIII (2),20-34.

Einarsen, S (2005).The Nature, Causesand Consequences of Bullying at Work: The Norwegian Experience. Perspectives interdisciplinaires sur le travail et la santé 7-3, 2005, mis en ligne le 01 Novembre 2005.

Eskiyörük, D. (2010). Halkla İlişkiler Uygulayıcıları Rol Modellerinde Örgüt Kültürünün Etkisi ve Hastane İşletmelerinde Bir Uygulama. Yayımlanmamış Doktora Tezi. Çukurova Üniversitesi Sosyal Bilimler Enstitüsü İşletme Anabilim Dalı.

Etyemez, H. (2013).1. Çalışma Hayatında Psikolojik Taciz (Mobbing) Paneli ve Çalıştayı. Ankara: Özyurt Matbaacilk.

Geçikli, F. ve Geçikli, M. (2012). İşyerlerinde Mobbing (Psikolojik-Şiddet) Sarmalında Kadın: Kamu Üniversitesinde Bir Uygulama. Uluslararası Katılımlı Kadına ve Çocuğa Karşı Şiddet Sempozyumu, 27-28 Nisan 2012, Ankara.

Güllüoğlu, Ö. (2006). Halkla İlişkiler Mesleğinde Etik Anlayışı. II. Ulusal Hakla İlişkiler Sempozyumu, 27-28 Nisan 2006, Kocaeli Üniversitesi.

Karasar, N. (2000). Bilimsel Araştırma Yöntemleri. Ankara: Nobel Yayın Dağıtım.

Karatuna, I. (2013). İşyerinde Psikolojik Tacizle Mücadele Yöntemler. I. Çalışma Hayatında Psikolojik Taciz (Mobbing) Panel ve Çalıştayı, Ankara, 2013. İstanbul: Özyurt Matbaacılık.

Karcıoğlu, F. ve Akbaş, S. (2010). İşyerinde Psikolojik Şiddet ve İş Tatmini İlişkisi. Atatürk Üniversitesi İktisadi ve İdari Bilimler Dergisi, 24 ( 3), 139-161.

Kazancı, M. (1980). Halkla İlişkiler. Ankara: A. Ü. Siyasal Bilgiler Fakültesi Yayınları, No. 459.

Keskin, A. ve Canbaz, S. (2014). KOBİ'lerde Çalışanların Mobbinge Maruz Kalma Durumları: Kırklareli İlinde Bir Araştırma. İGÜSBD, 1(2), 161-195.

Koç, M. ve Bulut, H. U. (2009).Ortaöğretim Öğretmenlerinde Mobbing: Cinsiyet Yaş ve Lise Türü Değişkenleri Açısından İncelenmesi. International Online Journal of Educational Sciences, 1 (1), 64 - 80.

Köse, H. (2006). Örgüt İçi İletiş̧imde Negatif Bir Olgu: Psikolojik Yıldırma ve Sistemli Bir "Ötekileştirme" Süreci Olarak Mobbing. II. Ulusal Hakla İlişkiler Sempozyumu, 27-28 Nisan 2006, Kocaeli Üniversitesi.

Leymann, H. (1990). Mobbing and Psychological Terror at Workplaces. Violence and Victims, 5 (2), 119-126. 
MEGEP (2007). Mesleki Eğitim ve Öğretim Sisteminin Güçlendirilmesi Projesi, Halkla İlişkiler ve Organizasyon Hizmetleri. Ankara: Milli Eğitim Bakanlığı.

Mobbing İle Mücadele Derneği (2011). http://www.mobbing.org.tr/tr/?p=940 (Erişim Tarihi: 01.09.2015).

Öner, Ş. (2001). Belediyelerde Yönetime Katılmada Halkla İlişkilerin Rolü ve Önemi. Dokuz Eylül Üniversitesi Sosyal Bilimler Enstitüsü Dergisi, 3(2), 101-114.

Özgan, H., Kara, M. ve Arslan, M. C. (2013). Öğretmenlerin Okul Yöneticilerine Uyguladıkları Psikolojik Yıldırma Uygulamaları ve Etkileri. Anadolu Eğitim Liderliği ve Öğretim Dergisi, 1 (1), 2-14.

Özkan, A. (2009). Halkla İlişkiler Yönetimi. İstanbul: İstanbul Ticaret Odası Yayınları.

Palaz, S., Özkan, S., Sarı, N., Göze, F., Şahin, N. ve Akkurt, Ö. (2008). İş Yerinde Psikolojik Taciz (Mobbing) Davranışları Üzerine Bir Araştırma; Bandırma Örneği. İş,Güç” Endüstri İlişkileri ve İnsan Kaynakları Dergisi,10(4), 41-58.

Seyidoğlu, H. (1997). Bilimsel Araştırma ve Yazma El Kitabı. İstanbul: Güzem Yayınları.

Shallcross, L., Sheehan, M. ve Ramsay, S. (2008). Workplace Mobbing: Experiences in the Public Sector. International Journal of Organisational Behaviour, 13(2), 56-70.

SHARP (2011). Safety, Health Assesment \& Research for Prevention. Workplace Bullying and Disruptive Behavior. Washington State Departman of Labor \& Industries.

Shelton. L. T. (2011). Mobbing, Bullying \& Harassment: A Silent Dilemma in The Workplace. Master of Science. Department of Rehabilitation In the Graduate School Southern Illinois University Carbondale.

Sloan, M. L., Matyók, T., Schmitz , C.L. ve Short, G.F. L. (2010). A Story to Tell: Bullying and Mobbing in the Workplace. International Journal of Business and Social Science, 1 (3), 87-97.

Sümer, F. E. (2013).Türkiye’de Stratejik Halkla İlişkiler Anlayışı: Türkiye’deki Büyük İş Örgütlerinin Halkla İlişkiler Uygulayıcılarına Yönelik Bir Araştırma. Global Media Journal,4, 51-80.

Taş, İ.E. ve Kestellioğlu, G. (2011). Halkla İlişkilerde İnternetin Yeri ve Önemi. Kahramanmaraş Sütçü İmam Üniversitesi İ̇BF Dergisi,11,73-92.

Taştekin, E. (2007). Emniyet Teşkilatında Halkla İlişkiler: Konya İl Emniyet Müdürlüğü Örneği. Yayımlanmamış Yüksek Lisans Tezi. Selçuk Üniversitesi Sosyal Bilimler Enstitüsü Halkla İlişkiler Ve Tanıtım Anabilim Dalı Hakla İlişkiler Bilim Dalı.

Tetik, S. (2010). Mobbing Kavramı: Birey ve Örgütler Açısından Önemi. KMÜ Sosyal ve Ekonomik Araştırmalar Dergisi, 12 (18), 81-89.

Tınaz, P. (2013). Çalışma Psikolojisi Boyutlarıyla Mobbing Tanım ve Tanı. I. Çalışma Hayatında Psikolojik Taciz (Mobbing) Panel ve Çalıştayı, Ankara, 2013. İstanbul: Özyurt Matbaacılık, 21-34.

Turan, F. (2006). İşyerlerinde Psikolojik Yıldırma Olgusu ve Konuya İlişkin Bir Araştırma. Yayımlanmamış Yüksek Lisans Tezi, İstanbul Üniversitesi, Sosyal Bilimler Enstitüsü, İșletme Anabilim Dalı, İnsan Kaynakları Yönetimi Bilim Dalı.

Ustakara, F. (2011). Halkla İlişkiler ve Psikoloji İlişkisi Üzerine. Gümüşhane Üniversitesi İletişim Fakültesi Elektronik Dergisi, 1,170-185.

Vural, A. B. ve Coşkun; G. (2006). Yeni Teknolojiler ve Halkla İlişkiler: Halkla İlişskiler Alanında Internet Kullanımı Üzerine Bir Araştırma. II. Ulusal Hakla İlişkiler Sempozyumu, 27-28 Nisan 2006, Kocaeli Üniversitesi.

Yıldırım, A. ve Şimşek, H. (2006). Sosyal Bilimlerde Nitel Araştırma Yöntemleri. Ankara: Seçkin Yayıncılık.

Yıldırım, S. (2008) Kurumlarda Halkla İlişkilerin Önemi. http://www.kocaeliaydinlarocagi.org.tr(Erişim: 14.10.2016).

Yıldız, N. (2006).Halkla İlişkilerde Medya ve Kamuoyunu Bilgilendirme Yanılsaması. II. Ulusal Hakla İlişkiler Sempozyumu, 27-28 Nisan 2006, Kocaeli Üniversitesi.

Yılmaz, A., Özler, D. E. ve Mercan, N. (2008). Mobbing ve Örgüt İklimi İle İlişkisine Yönelik Ampirik Bir Araştırma. Elektronik Sosyal Bilimler Dergisi, 7 (26), 334-357. 


\section{SUMMARY}

\section{Mobbing Case within Public Relations Profession}

Keywords: Public relations; mobbing; psychology of workers

\section{Introduction}

In an environment where global competition is so high, businesses cannot have the luxury to miss a risk regarding employees and organization, even it is a small detail. Today, mobbing, which carries the potential to spoil workers, groups and organizations, is at the forefront of these risks. Mobbing, whether public or private, is a major psychosocial problem in today's businesses. Although mobbing is associated with many reasons, it is basically a communication problem. This case makes mobbing a primary concern for "public relations", which is the unit responsible for communication within businesses.

What makes mobbing a "primary problem" for public relations profession is the fact that it has the risk to damage the functions of the public relations in the business. Because, mobbing, in many contexts, is a communication obstacle basically. Just as the public relations unit is important for achieving the goals of a business, the reputation and functionality of this unit is also dependent on its ability to recognize and fight against mobbing. Mobbing is one of the serious communication problems for the businesses today. So, it is important to examine mobbing, which is generally emphasized in its administrative and legal aspects, in the context of public relations.

\section{Method}

This study, which aims to examine mobbing within public relations profession, was carried out in the literature survey model. In this theoretical study which was conducted as a documentary analysis; books, papers and reports with scientific qualities in the written and electronic literature were examined in order to determine the relation between public relations and mobbing. The examined documents were collected under three headings in the direction of the aim of the study and some results were obtained.

\section{Definition and Importance of Public Relations}

There are many definitions of public relations, such as many other concepts in social and human sciences. An important reason of this is that public relations is an interdisciplinary and deeply rooted area. Despite these roots which can be taken up to Ancient Greece, public relations was mentioned in 1950 in the world, and after 1908s in Turkey. In its broadest sense, public relations is "publicity and recognition efforts". Public relations, which is an attempt to mobilize public support for an institution through "information and persuasion", is a kind of " molding public opinion". Even though it has many functions, communication lies at the heart of public relations. As a profession, public relations is interdisciplinary. To- 
day, public relations have an importance that cannot be ignored in the way that organizations achieve their goal. Public relations is both the insurance and the showcase of an organization. Public relations, with its perception management and image provisioning functions, is closely related to the reputation of the business.

\section{Mobbing Concept}

Mobbing is a concept that can be dealt with in many different contexts. In this study, mobbing was mostly discussed in the context of interpersonal communication and interaction problem in the workplace. In its broadest sense, mobbing, which is a communication obstacle and makes it hard to work, is unwanted psychosocial behaviors that an employee is exposed to. These behaviors are systematic emotional attacks and attrition movements. Mobbing can also be described as hostile acts and aggressions that cause reputational loss in the employee. Mobbing is a psychological harassment in the workplace and a case that threatens employee's competence by gossiping, intimidation, isolation and humiliating. While mobbing covers secret rumor, gossip and hint of irony, it does not cover job jokes, examples of unethical behavior, and isolation conflicts at work. The causes of mobbing can be listed as intolerant management, lack of open communication channels, competition, working conditions, personal and cultural factors. Recent studies have shown that mobbing is very common in Turkey as well as in the world. Mobbing, which is mainly a communication problem, should be approached as a public relations problem.

\section{Results}

In recent years, as in every field, the human factor comes to the forefront in business life. Parallel to this, public relations unit attracts attention as never before. Because public relations unit represents the face of the organization that is directly related to people. The person who is brought to the foreground here is the "whole person" who works in a workplace. The whole human, composed of the body, mind, heart and spirit, can only fully reveal his potential when this integrity is ensured. What happens in an organization, when its employees' only mind and body are appealed and their feelings and spirit are ignored? There occurs a "low trust" that forms the basis of many problems in working life. Low trust in a business can cost much both personally and institutionally. This cost can be summarized as restless workers, and therefore low-efficient businesses that do not fully utilize the potential of these workers. What a great loss and waste! Especially for the public relations unit which is based on principles of honesty, credibility and reliability. In the construction of institutional trust, which is very important in overcoming the problem, public relations play a crucial role. In order public relations play this role, it is expected to know about its employees' human characteristics well. At this point, mobbing, which is closely related to the mental health of a person, stands out as the priority issue and problem of public relations. Therefore, public relations can solve the problem by focusing on the dimension of psychological design. For this, public relations profession should be related to psychology and social psychology as much as it is related to communication, law, management, politics, sociology, ergonomics and ethics. 